IRA-International Journal of Education \& Multidisciplinary Studies

ISSN 2455-2526; Vol.16, Issue 02 (April-June, 2020)

Pg. no. 112-122.

Institute of Research Advances

https://research-advances.org/index.php/IJEMS

\title{
Assessment of Availability and Use of Teaching and Learning Resources for Retention of Learners with Special Needs in Regular Primary Schools in Dadaab Sub-County, Kenya
}

Dure Mohammed Osman ${ }^{1 \#}$, Oracha, P. A. ${ }^{2}$ and Okutoyi Joel ${ }^{3}$

1,2,3 Department of Special Needs Education, Maseno University, Maseno, Kenya.

\# corresponding author

Type of Work: Peer-Reviewed

DOl: http://dx.doi.org/10.21013/jems.v16.n2.p4

\section{How to cite this paper:}

Osman, D.M., Oracha, P.A., Joel, O. (2020). Assessment of availability and Use of Teaching and Learning Resources for Retention of Learners with Special Needs in Regular Primary Schools in Dadaab Sub-County, Kenya. IRA International Journal of Education and Multidisciplinary Studies (ISSN 2455-2526), 16(2), 112-122. DOI: http://dx.doi.org/10.21013/jems.v16.n2.p4

(C) Institute of Research Advances.

This work is licensed under a Creative Commons Attribution-Non Commercial 4.0 International License subject to a proper citation to the publication source of the work.

Disclaimer: The scholarly papers as reviewed and published by the Institute of Research Advances (IRA) are the views and opinions of their respective authors and are not the views or opinions of the IRA. The IRA disclaims of any harm or loss caused due to the published content to any party.

Institute of Research Advances is an institutional publisher member of Publishers International Linking Association Inc. (PILA-CrossRef), USA. The institute is an institutional signatory to the Budapest Open Access Initiative, Hungary advocating the open-access of scientific and scholarly knowledge. The Institute is a registered content provider under Open Access Initiative Protocol for Metadata Harvesting (OAI-PMH).

The journal is indexed \& included in WorldCat Discovery Service (USA), CrossRef Metadata Search (USA), WorldCat (USA), OCLC (USA), Open J-Gate (India), EZB (Germany) Scilit (Switzerland), Airiti (China), Bielefeld Academic Search Engine (BASE) of Bielefeld University, Germany, PKP Index of Simon Fraser University, Canada. 


\begin{abstract}
The status of implementation of inclusive education in terms of availability and use of teaching and learning resources for retention of learners with special needs in Garissa County was unknown. Inclusive education refers to a situation where learners with disabilities and special educational needs have full membership in age-appropriate classes in their regular neighborhood schools with appropriate supplementary aids and support services. Records from Educational Assessment and Resource Centres (EARC) Garissa County revealed that there was a decline in the retention rate of learners` admitted. For example, in the year 2014, the retention rate was 37 learners (45.7\%), 2015 (114 learners, 38.0\%), 2016 (43 learners, 28.9\%), 2017 (35 learners, 31.5\%) and 2018 (41 learners, 23.7\%). The purpose of the study was to assess the status of implementation of inclusive education practices for the retention of learners with special needs in regular primary schools in Dadaab subcounty. The specific objective of the study was to establish the extent to which the availability and use of teaching and learning resources affect the retention of learners with special needs in regular primary schools in Dadaab sub-county. The study adopted a descriptive survey research design. The target population comprised 26 head-teachers, 78 teachers, 300 learners with special needs, and 4 education officers. Saturated sampling technique was used to select 23 head-teachers, 70 teachers, 100 learners with special needs, and 4 education officers. Instruments for data collection were questionnaires, interview schedules and observation schedules. Quantitative data were analyzed using frequency counts, percentages, and mean. The findings of the study indicated that the availability and use of teaching and learning materials were inadequate (mean $=2.18$ ). The study concluded that the low retention of learners with special needs as a result of the availability and use of teaching and learning materials to a small extent. The study recommended that the country and national government should ensure that there is adequate provision of teaching and learning resources to enhance learning for learners with special needs. The budget for materials should be enhanced. The study also recommends to non-governmental organizations to assist regular primary schools to access teaching and learning materials that can be used by learners with special needs.
\end{abstract}

Keywords: Inclusive education; Retention; learners with special needs; Teaching and learning materials.

\title{
Introduction
}

According to the Government of Kenya (2009), learners with special needs are those who have learning disabilities or difficulties which requires adjustment to the methods of teaching, materials, and curriculum or delivery methods. Special needs education currently includes learners with hearing impairments, visual impairments, physical impairments, cerebral palsy, epilepsy, and mental handicaps. Also, those with Down syndrome, autism, emotional and behavioral disorders, learning disabilities, speech and language disorders, multiple handicaps, and albinism are classified as learners with special needs. Educational opportunities for learners with special needs and disabilities are a major challenge to the education sector(Wafula, 2012). The majority of learners with Special Needs and Disabilities in Kenya do not access educational services. For instance, in 2009 there were only 42,000learners with special needs and disabilities enrolled in special schools, units, and integrated programs. This number rose to 66,885 in 2013 and 75,000 in 2016, which compares poorly with the proportion in general education(Mutugi, 2018).

The concept of inclusive education is based on the fact that all children and young people despite cultural social and learning backgrounds should have equivalent learning opportunities in all kinds of schools (UNESCO, 2008). UNESCO emphasizes that education systems schools and teachers should focus on generating inclusive settings that uphold the values of respect and understanding of cultural, social, and individual diversity. Inclusive education is an approach that looks into how to transform education systems and other learning environments to respond to the diversity of learners. Removing barriers to participation in learning for all learners is at the core of an inclusive education system (UNESCO, 2005) focusing on inclusive education can be useful in guiding the development of policies and strategies that address the caused and consequences of discrimination inequality and exclusion within the holistic framework of EFA goals.

Education for All (EFA) identified inclusive education as one of the key strategies to address issues of marginalization and exclusion. In this view, the government of Kenya has been implementing measures to 
improve the participation of special needs learners in mainstream schools. Despite efforts made by the government access to education by those with special needs remains limited as pointed out by Njoka $e t$ al (2012) in their study of equitable basic educational Kenya found out that special needs education has not been given special attention. It has been argued that inclusive schools will not become a reality unless there is leadership for inclusion. Hence proactive school management requires the school leadership to assume responsibility for ensuring that inclusive values and practices are well understood and applied daily (New Brunswick Association for community living (2007). Similarly, a study by the National Down Syndrome Society (2008) on what makes inclusive education successful indicated that the degree of administrative support and vision is the most powerful predictor of the general educator attitude towards full inclusion.

Various studies have been conducted investigating the role of inclusive education practices in enabling retention of learners with special needs in regular primary schools. Regarding the effect of availability and use of teaching and learning resources in enabling retention of learners, Okutoyi, Kochung and Kabuka (2013) carried out a study on support services and resources in regular primary schools with hearing impaired learners in Kakamega County, Kenya. The purpose of the study was to establish support services available in regular primary schools to help learners with hearing impairment cope. The study established that key support services and resources employed included the use of special needs education teachers in classrooms, the use of sign language in teaching, audiological assessment, individualized instructions, speech, and language training. Besides, the use of visual aids such as charts, pictures, real objects, and teaching models were used to enhance the understanding of learners with hearing impairment.

The study by Okutoyi et al (2013) only focused on teaching-learning resources for learners with hearing impairment. This study addressed other areas of special needs such as physical challenges, visual impairment, and mentally challenged. Moreover, the study by Okutoyi et al. (2013) was conducted in Kakamega County, Kenya while this study was conducted in Garissa which has a different socio-economic context from Kakamega. The findings by Okutoyi et al. (2013) supported previous findings by Mutisya (2010) that the availability of teaching resources and support services increasing the retention rate of learners with special needs in regular primary schools. This study was, however, conducted in Rachuonyo which depicts different contexts from the context in Garissa.

The basic education sector in Kenya has experienced an expansion in enrollment since independence in 1963, according to ministry's education management institute information system (EMIS), the number of both public and private primary schools increased from 6058 in 1963 to 27289 in 2010 (Republic of Kenya 2012: 11). Enrolment in primary education has grown from 892,000 pupils in 1963 to about 9.4 million pupils in 2010 (Republic of Kenya, 2013). The increase has been accelerated by the introduction of free primary education and education for All (Republic of Kenya, 2012).

While these statistics portray a success story at the national level, the situation is now disappointing at the county level even though there is no discrimination in various government policies to guide special needs education. The government provided education for children with disabilities through integrated units in schools. However, the lack of clear implementation framework of special needs education policy, inadequate funding, and inadequate teachers with the right skills to teach learners with disabilities has indicated low retention of special needs learners in schools. The North-Eastern part of Kenya has registered low retention rate of learners with special needs despite challenged by several factors; poverty at household level, insecurity, retrogressive socio-cultural practices, conflict between religious and secular education system, low parental assistance with homework for children, low premium attached to education and unconducive learning home environment.

A baseline study carried out in the Dadaab sub-county indicates that there has been low retention of learners with special needs in regular schools. As indicated in Table 1. 
Table 1: Retention Rate of Learners with Special Needs in Regular Primary Schools in Dadaab Subcounty

\begin{tabular}{lllll}
\hline Year & $\begin{array}{l}\text { No. of learners } \\
\text { with SN } \\
\text { admitted }\end{array}$ & $\begin{array}{l}\text { No. Dropped out } \\
\text { of school at the } \\
\text { end of the year }\end{array}$ & $\begin{array}{l}\text { Number of } \\
\text { with SN } \\
\text { retained }\end{array}$ & Retention rate \\
\hline 2014 & 81 & 44 & 37 & 45.7 \\
2015 & 300 & 186 & 114 & 38.0 \\
2016 & 149 & 106 & 43 & 28.9 \\
2017 & 111 & 76 & 35 & 31.5 \\
2018 & 173 & 132 & 41 & 23.7 \\
\hline
\end{tabular}

Source: EARC, Garissa 2018

From Table 1, it is evident that there is a low retention rate of learners admitted. For example, in the year 2014, the retention rate was 45.7 percent, 2015 (38.0\%), 2016 (28.9\%), 2017 (31.5\%), and 2018 (23.7\%). These findings indicate a general decline in the retention rate over the years from $45.7 \%$ in 2014 to $23.7 \%$ in 2018. This puts into question the status of inclusive education in terms of teaching-learning strategies, attitudes, resources, and curriculum. There is a need for a study to be carried out to determine the status of inclusive of learners with special needs in Dadaab sub-county, Garissa County in Kenya.

According to the survey conducted by the National Coordinating Agency for Population Development Kenya (NCAPD, 2007) on persons with disabilities, North Eastern province indicated the lowest number of PWD. However, there is a worrying trend as it is the one leading with low retention of learners with special needs in schools.

Table 2: Distribution of PWDs across the Country per Province

\begin{tabular}{llllll}
\hline \multicolumn{5}{c}{} & \multicolumn{2}{c}{ Population by Background Statistics } \\
& & \% Male & \% Female & \% & Number \\
\hline Residence & Rural & 49.5 & 50.5 & 100.0 & 56250 \\
& urban & 50.1 & 49.9 & 100.0 & 14441 \\
Province & Nairobi & 50.6 & 49.4 & 100.0 & 5769 \\
& Central & 48.8 & 51.2 & 100.0 & 8663 \\
& Coast & 50.3 & 49.7 & 100.0 & 6137 \\
& Eastern & 49.0 & 51.0 & 100.0 & 11030 \\
& North Eastern & 52.2 & 47.8 & 100.0 & 2498 \\
& Nyanza & 49.0 & 51.0 & 100.0 & 10350 \\
& Rift Valley & 50.3 & 49.9 & 100.0 & 17875 \\
TOTAL & Western & 48.7 & 51.3 & 100.0 & 8369 \\
\hline
\end{tabular}

Source: NCAPD; Data 2007

In some communities, PWDs are discriminated against as a result of their condition and thus making it hard for them to access education. This was also revealed by NCAPD (2007) as shown in Table 3, interestingly North Eastern records low numbers of special needs learners accessing education which also decreases from enrolment to no learner making past secondary school. Table 3 shows the educational attendance of persons with disabilities in regular schools. 
IRA-International Journal of Education छ Multidisciplinary Studies

Table 3:PWDs' Educational Attendance in Mainstream/regular school

\begin{tabular}{llllllll}
\hline \multicolumn{7}{c}{} & \multicolumn{2}{c}{$\begin{array}{l}\text { Population by Background Statistics } \\
\text { Preschool }\end{array}$} & $\begin{array}{l}\text { Primary } \\
\text { school }\end{array}$ & Secondary & Tertiary & Vocational & Number \\
\hline Residence & Rural & 38.7 & 35.9 & 6.0 & 1.5 & 0.7 & 2447 \\
& Urban & 42.0 & 40.0 & 19.0 & 7.0 & 2.4 & 648 \\
& & & & & & & \\
Province & Nairobi & 44.7 & 44.7 & 22.6 & 9.2 & 3.3 & 279 \\
& & & & & & & \\
& Central & 29.3 & 28.1 & 6.9 & 2.0 & 0.1 & 427 \\
& Coast & 39.8 & 36.0 & 7.7 & 3.2 & 1.6 & 304 \\
& Eastern & 42.4 & 40.0 & 6.3 & 2.2 & 1.0 & 523 \\
& North Eastern & 5.3 & 9.9 & 0.6 & 0.0 & 00 & 66 \\
& Nyanza & 44.2 & 40.3 & 8.2 & 1.6 & 0.9 & 674 \\
& Rift Valley & 36.5 & 33.5 & 10.2 & 2.5 & 1.4 & 554 \\
TOTAL & Western & 48.7 & 41.9 & 3.8 & 0.3 & 0.0 & 268 \\
& & & & & & & $\mathbf{6 1 9 0}$ \\
\hline
\end{tabular}

Source: NCAPD Data 2007

From table 3, it is evident that learners with disabilities had low retention in the North-Eastern province.

Table 4 shows the number of learners with special needs in Garissa County as per the sub-county.

Table 4: Enrolment of Learners with Special Needs in regular schools in Garissa County in 2018

\begin{tabular}{lll}
\hline & Sub-county & Number of learners with special needs \\
\hline 1 & Garissa township & 320 \\
2. & Ijara & 380 \\
3. & Ladgera & 473 \\
4. & Balambala & 395 \\
5. & Fafi & 401 \\
6. & Hulugho & 351 \\
7. & Dadaab & 300 \\
\hline \multicolumn{2}{l}{ Source: } & EARC, Garissa 2018
\end{tabular}

From Table 4, it is evident Dadaab had the least number of learners with special needs who had been retained in the regular schools by the year 2018. Therefore, the study was carried out in Dadaab as it had the least number of learners with special needs who had been retained.

\subsection{Statement of the Problem}

Inclusive education is advocated for by the government of Kenya where learners with special educational needs should learn along with the regular counterparts in the regular neighborhood schools. This should be realized through the policy document which is reflected in the special education policy. The retention rate of learners admitted in regular primary schools in Dadaab Sub-county is decreasing. In the year 2014, the retention rate was 45.7 percent, 2015 (38.0\%), 2016 (28.9\%), 2017 (31.5\%), and 2018 (23.7\%). It is evident from the figures that there is a low retention rate of learners with special needs in Dadaab subcounty giving rise to low retention of learners with special educational needs. The status of inclusive education in terms of the availability of teaching and learning materials was unknown.

Various studies had been conducted regarding factors influencing the retention of learners with special needs in regular schools. However, most of these studies only considered curricular adaptations and failed to focus on the availability of teaching and learning materials. There is, therefore, a need for a study to be carried out to determine the status of inclusive learning in Dadaab sub-county, Garissa County in Kenya. This study was therefore set to find out the availability and use of teaching and teaching resources and their 
influence on retention of learners with special needs in regular primary schools in Dadaab sub-county, Garissa County in Kenya.

\section{Literature Review}

A study by Wafula (2012)on adequacy and utilization of teaching resources for learners with slow learning abilities in Nyanza reveals that adequacy of resources for the instruction of learners with learning disabilities can make a difference in their lives. The teacher's first responsibility is to ensure that the class used by special needs learners are adequately resourced. Resources should be available as much as possible and they should be sufficient to encourage imaginative use. Availability and adequacy of a wide variety of instructional resources and from many sources can stimulate learning. Special needs learners are known to be less able to grasp abstract concepts when compared with learners of normal intelligence. The more meaningful and concrete the material, the more the opportunities for the special needs learners to learn. Teaching resources enable children to gain a sense of pride in their own choices and differences. Giving children objects to handle helps them to listen and attend to and this enables them to remain alert as this acts as another sensory boost. Learners with special needs have a short attention span and memory problems and therefore, the use of instructional resources is of critical importance in their learning. Learners with special needs require numerous verbal, physical, and visual prompts to redirect their attention and encourage their participation in familiar entities and minimize distractive activities such as wiggling in their seats, engaging in inappropriate behavior, attempting to escape or just gazing around the room. Introducing new concepts and skills while reinforcing using materials makes such children learn.

Teachers can create opportunities for learners with special needs to experience success by selecting materials that are in line with the learner's level of ability. Learners who associate pleasure and success in reading will be motivated to read hence learn. When teachers present new material in a decontextualized form, they tend to create a very different setting from what the learners already know. In this, teachers risk

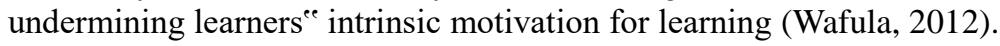

Inciong and Quijano (2014) emphasized that classrooms need to be colorful and interesting for learners to feel enthusiastic about coming to pre-school centers. For easy access, ramps (for children with disabilities), handrails (for children with visual impairment), Braille for reading and writing, and wheelchairs are needed. A mug and a bucket of water too may be kept outside the classroom to ensure that learners maintain basic hygiene by washing their hands after playing outside. Avramidis and Norwich (2012), noted social facilities to accommodate learners with special needs are often nonexistent or inadequate in many institutions. Few facilities may be found within the urban centers but none in the rural areas.

According to the Republic of Kenya (2009), the cost of services for learners with special education is relatively high and consists of the most limiting factor against increasing enrolment, retention, and transition of such learners within education programs. The government is providing adequate specialized teaching staff although there is retardation faced in having required numbers. The learners required specialized materials for their education than non-disabled (UNICEF, 2007). These materials are needed at both schools and individual levels. The physical environment should be accessible to them and be friendly. The government allocates material resources to improve physical structures and provide individual learners with basic learning aids under FPE; every Kenyan child receives Ksh 1020 and Ksh 2000 respectively for tuition annually. This is not adequate for the learners with special needs who need more than specialized resources. These will be supplemented by other service providers which include: individuals, faith organizations, civil society organizations, the corporate sector, bilateral and multilateral agencies (Republic of Kenya, 2012).

The financing of special education remains a challenge to the government. The government spends $0.2 \%$ of the total education budget on special education which inadequate(Mutugi, 2018). Consequently, most of the financing comes from civil societies, particularly local and international NGOs. Given the constitution of Kenya (2010) its commitment to international protocols on the rights of children and its commitment to EFA goals, a framework incorporating the financing requirements of special education should be established. 
The issues affecting other areas of special education services in Kenya also affect the delivery of services for learners with disabilities. Among these, lack of vital human and material resources(Mutugi, 2018). The other is a lack of law of vital that mandates funds and enforces educational and other services for all learners with disabilities. In the education for disability, the law is required to provide and enforce services for this population, Mukuria and Obiakor (2006). Without these laws, many learners with disabilities are likely to be locked out.

The adequacy of teaching-learning resources determines the success or failure of the educational system. A method of determining the extent of teachers' adequacy is through the student-teacher ratio which is the number of students assigned to teachers for teaching(Avramidis \& Norwich, 2012). The student-teacher ratio is used to determine the number of students that are to be allocated to a teacher in a given educational level. The student-teacher ratio shows a teacher's workload at a particular level of education. It also helps in determining the numbers of teaching manpower needed for a projected student enrolment, thus, it could be used to determine either teachers are over-utilized or underutilized (Kang \& Martin, 2018).

Material resources include textbooks, charts, and maps audiovisual and electronic instructional materials such as radio, tape recorder, television, and videotape recorders. Other categories of materials resources consists of paper supplies and wring materials such as pens, eraser, exercise books, crayon, chalk, drawing books notebooks, pencil ruler, state and workbooks (Marsh \& Scalas, 2010). Efthymiou and Kington (2017), discovered a very strong positive significant relationship between instructional resources and academic performance. Schools endowed with more materials performed better than schools that are less endowed.

Oyugi and Nyagi (2010) noted that teaching and learning resources include; peripatetic services, support staff (sign language interpreters and Braille transcribers), community involvement, regular and special teacher among others. Inadequate trained teachers and professionals act as an obstacle to the implementation of inclusive education (Kochung, 2011). Besides, Chalkadirayons (2013) stated that for the development of reading, writing, and listening skills are necessary supplies for classrooms like lesson plans, workbooks, textbooks, bulletin boards, writing materials, and organization materials should be available by the teacher as essential classroom supplies.

Okutoyi et al. (2013) carried out a study on support services and resources in regular primary schools with hearing impaired learners in Kakamega County, Kenya. The purpose of the study was to establish support services available in regular primary schools to help learners with hearing impairment cope. The population of the study consisted of 121 learners with H, 1584 hearing learners, 36 teachers, and 18 head-teachers. The sample size consisted of 480 hearing learners, $109 \mathrm{HI}$ learners, 32 teachers, and 16 Head-teachers. Findings indicated that key support services and resources employed included: use of SNE teachers in classrooms use sign language in teaching, audiological assessment, individualized instructions, speech, and language training. Also, the use of visual aids such as charts, pictures, real objects, and teaching models were used to enhance the understanding of learners with hearing impairment.

Although the area of study bear similarities to Okutoyi et al. (2013) regarding resources. However, the present study will find out teaching /learning resources for learners with various special needs such as visually impaired, mentally handicapped, physically handicapped and hearing impaired. According to Broer, Bai, and Fonseca (2019), teachers need to shelter their instruction by following the among other things, teachers differentiating their instructions by giving students with beginning levels of proficiency opportunities to learn new raw material in ways that do not rely on language.

Universal Design for learning is meant to meet the diverse needs of learners for learning by diverse goals, materials, methods, and assessment. Through universal design for learning, teachers develop appropriate goals designed to address the needs of a wide range of students and implement instructional methods responsive to individual differences (Seo, Kim, \& Shin, 2014). In a school committed to a high level of learning for all students, research has shown that specialists and support staff develop affection, collaborative, trans-disciplinary support system for teachers, students, and families, such schools use specialized school and community resources to strengthen the general education classroom, developing 
support terms(Seung-mo, 2016).Alper and Ryndak (2013).Scheeler, Congdon, and Stansbery (2010)and Oyugi and Nyagi(2010) studies focused on various teaching-learning resources. However, the three studies did not establish the extent to which the use of teaching-learning resources in inclusive schools influenced the retention of learners with special needs in regular schools. These necessitated the present study.

\section{Methodology and Materials}

The study adopted a descriptive survey design. This design was used because it involves collecting data from various population members, offers the ability to understand a population from part of it and it is suitable for extensive research. Mixed methods (quantitative and qualitative approaches) were being adopted. The study was conducted in Dadaab Sub-County which in the North-Eastern Part of Kenya. The sub-county is Latitude $0^{\circ} \mathrm{N}$ and Longitude $40^{\circ}$ E. Dadaab sub-county has some of the largest refugee camps in Kenya. The four camps are Hagadera, Dagahaley, Ifo, and Kambi Hoss while 26 primary schools were targeted. The target population comprised of 26 head-teachers, 78 teachers, 300 learners with special needs, and 4 education officers. Purposive, simple random, and saturated sampling techniques were used in this study. Purposive sampling was used to select schools that had learners with special needs in Dadaab Sub-County. Simple random sampling was used to select 100 learners with special needs. Saturated sampling technique was used to select 70 teachers and 23 head-teachers for the actual study. Saturated sampling technique ensures all participants take part in the study. The technique ensures all categories of the population presented were included in the sample (Best and Khan, 2006).

The study used questionnaires, interview schedules, observation schedules and focus group discussions as the instruments of data collection. The questionnaires were for learners, teachers, head-teachers, and education officers. An interview schedule was used to get information from teachers and head-teachers. Focus group discussion was used to collect information from the education officers on the implementation of inclusive education of learners with special needs. An observational checklist was used for collecting data on learners' behavior with special needs. To establish content validity, the instruments were given to experts in the department of Special Needs Education to evaluate the relevance of each item in the instruments to the objectives. A pilot study was carried out to enhance reliability and help the researcher identify items in the research instruments that might be ambiguous in eliciting relevant information. This was done through the test-retest method where the researcher administered the instruments to the same subjects after two weeks.

Research permission was sought from Maseno University Ethics and Review Committee (MUERC). Thereafter, the Dadaab refugee camp education coordinator was contacted to provide access to learners with special needs. Further permission was sought from the District Education Officer (DEO). Later, the 16 head-teachers of the schools were contacted and permission sought. Further, the researcher visited the school to carry out interviews and distribute the questionnaires. The questionnaires and interview schedules were administered by the researcher with the assistance from class teachers. Observation was conducted as the teachers filled the questionnaires. Data collected from the questionnaires were coded manually before analyzing it using the statistical Package for Social Sciences (SPSS). Quantitative data were analyzed using frequency counts, percentages, and mean. Qualitative data was organized and reported in an on-going process as themes and sub-themes emerged.

\section{Results and Discussions}

The study administered 196 questionnaires. They were issues to 100 learners, 70 teachers 23 head-teachers, and three education officers. Regarding the availability of teaching-learning resources in regular primary schools, statements were issued to the respondents and respondents were required to rate the extent that those statements applied to their schools on a scale of $1-5(1-$ Not applicable - NA, 2 - very small extent - VSE, 3 - Small extent - SE, 4 - Large extent - LE and 5 - very large extent - VLE). Percentages, frequencies, and means were used. The results are presented in Table 1.

The study further sought to establish the availability of teaching-learning resources in regular primary schools. The teachers were asked to give their views on a variety of aspects encompassing the availability of teaching-learning resources. These included whether they helped learners with special needs that had a problem in reading and writing comprehension, and spelling through IEP; diagnostic prescriptive, 
availability and use of special desks, chairs, boards and writing material for learners with special needs; use of hearing aids when teaching learners with special needs; Speech training units are available and used in this school; and availability and use of Drums, jingles, shakers and flashcards, mirrors and speech kids when teaching for learners with special needs. The results were presented as shown in Table 8 .

Table 8: Availability and use of Teaching-Learning Materials

\begin{tabular}{|c|c|c|c|c|c|c|}
\hline $\begin{array}{l}\text { Teaching-learning } \\
\text { resources }\end{array}$ & $\begin{array}{l}\text { VLE } \\
\text { f }(\%)\end{array}$ & $\begin{array}{l}\text { LE } \\
\mathbf{f}(\%)\end{array}$ & $\begin{array}{l}\text { SE } \\
\mathbf{f}(\%)\end{array}$ & $\begin{array}{l}\text { VSE } \\
\text { f }(\%)\end{array}$ & $\begin{array}{l}\text { N/A } \\
\text { f (\%) }\end{array}$ & Mean \\
\hline $\begin{array}{lll}\text { Learners with low vision } \\
\text { are provided with large } \\
\text { print materials }\end{array}$ & 25 (35.7) & $32(45.7)$ & $9(12.9)$ & $2(2.9)$ & $2(2.9)$ & 1.91 \\
\hline $\begin{array}{l}\text { Learners with residual } \\
\text { hearing use hearing aids to } \\
\text { boost hearing in class }\end{array}$ & $9(12.9)$ & $41(58.6)$ & $8(11.4)$ & $8(11.4)$ & $4(5.7)$ & 2.39 \\
\hline $\begin{array}{l}\text { Learners with physical } \\
\text { disability are provided with } \\
\text { crutches }\end{array}$ & $27(38.6)$ & $25(35.7)$ & $6(8.6)$ & $6(8.6)$ & $6(8.6)$ & 2.13 \\
\hline $\begin{array}{l}\text { Learners with physical } \\
\text { with grasping difficulties } \\
\text { use book holders in class }\end{array}$ & $9(12.9)$ & $31(44.3)$ & $8(11.4)$ & $15(21.4)$ & $7(10.0)$ & 2.71 \\
\hline $\begin{array}{l}\text { Learners with low vision } \\
\text { use embossed diagrams in } \\
\text { their learning }\end{array}$ & $12(17.1)$ & $36(51.4)$ & $10(14.3)$ & $9(12.9)$ & $3(4.3)$ & 2.36 \\
\hline $\begin{array}{l}\text { Learners with low vision } \\
\text { are provided with visual } \\
\text { aids during teaching- } \\
\text { learning process }\end{array}$ & $18(25.7)$ & $45(64.3)$ & $9(2.9)$ & $3(4.3)$ & $2(2.9)$ & 1.94 \\
\hline $\begin{array}{l}\text { Learners with physical } \\
\text { disability are provided with } \\
\text { low seats in their } \\
\text { classrooms }\end{array}$ & 23 (32.9) & $40(57.7)$ & $4(5.7)$ & $2(2.9)$ & $1(1.4)$ & 1.83 \\
\hline Grand Mean & & & & & & 2.18 \\
\hline
\end{tabular}

The results in Table 8, indicated that learners with low vision were not provided with large print materials as was indicated by a mean of 1.91 , the learners with residual hearing were provided with hearing aids $($ mean $=2.39)$, provision for crutches to the physically disabled learners $($ mean $=2.13)$, learners with physical grasping difficulties used book holders in class (mean= 2.71), learners with low vision used embossed diagrams in their learning (mean= 2.36), low with the vision provided with visual aids during teaching-learning process $($ mean $=1.94)$ and provision of low seats to learners with a physical disability (mean= 1.83). The grand mean was 2.18 indicating that the availability and use of teaching-learning materials in regular schools in Dadaab Sub-county was to a small extent. This implied that the extent to which teaching-learning materials were used was inadequate.

An interview with the education officers revealed a hint on the availability of teaching-learning resources and their relation to learners with special needs. They were asked to share their views on the availability of teaching-learning resources in Dadaab sub-county Garissa county, Kenya primary schools. Education officer two;

"In this sub-county, there are lots of teachers who have been teaching for a long period. We find that the more the teacher teaches, the more they learn how to handle learners. Therefore when teachers have enough experience, they tend to teach more effectively. But on the other hand, the strategies used for teaching and even for learning are not sufficient for learners with special needs. They need to be reformed.' 
This statement indicated that the education officers and teachers did not see the need for teaching and learning materials to cater specifically for students with special needs. This can disadvantage learners with special needs. The results also show that there are limited teaching and learning materials for learners with special needs in schools in Dadaab sub-county Garissa County. This indicates that learners with learning difficulties would not be well catered for in the regular primary schools. This study findings are in line with Eleweke and Rodda (2002) who noted that social facilities to accommodate learners with special needs are often nonexistent or inadequate in many institutions. Few facilities may be found within the urban centers but none in the rural areas. These study findings indicated that most regular primary schools in Dadaab subcounty did not have adequate learning materials and resources to accommodate learners with special needs.

\section{Conclusions and Recommendations}

The study revealed that the extent to which the availability and use of teaching-learning resources in regular schools in Dadaab Sub-county was to a smaller extent. This led to the low retention of learners with special needs in regular primary schools. Based on the findings of the study, the study recommends that the ministry of education in partnership with the other education stakeholders and NGOs should provide adequate teaching and learning resources to ensure that learners with special needs in regular primary schools get the quality education they deserve.

\section{References}

[1]. Alper, S., \& Ryndak, D. L. (2013). Educating Students with Severe Handicaps in Regular Classes. The Elementary School Journal, 92(3), 373-387. https://doi.org/10.1086/461698

[2]. Avramidis, E., \& Norwich, B. (2012). Teachers' attitudes towards integration/inclusion: A review of the literature. European Journal of Special Needs Education. https://doi.org/10.1080/08856250210129056

[3]. Best, C. E. \& Khan D. (2008). The Quality of Education in Developing Countries. Kingsley. Labour Market. Paris: Macmillan.

[4]. Broer, M., Bai, Y., \& Fonseca, F. (2019). Socioeconomic Achievement Gaps: Trend Results for Education Systems. In \{IEA $\}$ Research for Education (pp. 35-70). Springer International Publishing. https://doi.org/10.1007/978-3-030-11991-1_4

[5]. Efthymiou, E., \& Kington, A. (2017, January 1). The development of inclusive learning relationships in mainstream settings: A multimodal perspective. Cogent Education. Taylor and Francis Ltd. https://doi.org/10.1080/2331186X.2017.1304015

[6]. GOK, (2002). National Development Plan, (2002-2008) Effective Management for Sustainable Economic Growth and Poverty Reduction. Nairobi: Government Printers.

[7]. GOK, (2003). Report of Task Force on Implementation of Free Primary Education. Nairobi: Government Printers.

[8]. Government of Kenya. (2009). The national special needs education policy. Nairobi: Government Printers.

[9]. Inciong, T. G., \& Quijano, Y. S. (2014). Inclusion of Children with Disabilities: The Philippines Experience. Asia Pacific Journal of Education, 24(2), 173-191. https://doi.org/10.1080/02188791.2004.10600208

[10].Kang, D. Y., \& Martin, S. N. (2018b). Improving learning opportunities for special education needs (SEN) students by engaging pre-service science teachers in an informal experiential learning course. Asia Pacific Journal of Education, 1-29. https://doi.org/10.1080/02188791.2018.1505599

[11].Marsh, H. W., \& Scalas, L. F. (2010). Self-Concept in Learning: Reciprocal effects model between academic self-concept and academic achievement. In International Encyclopedia of Education (pp. 660-667). Elsevier. https://doi.org/10.1016/b978-0-08-044894-7.00619-9

[12].Mutisya, C. M. S. (2010). Factors influencing inclusion of learners with special needs in regular primary schools in Rachuonyo District, Kenya. Master In Education (Special Needs Education) Thesis, Kenyatta University.

[13].Mutugi, L. W. (2018). Learning challenges faced by special needs education learners in public primary schools in Mvita Division, Mombasa County, Kenya. University of Nairobi. https://doi.org/10.1017/CBO9781107415324.004

[14].New Brunswick community living (2007) Brief on system C barriers to implementation of inclusive education in New Brunswick.

[15].Njoka, E. Riechi, A Abiero C. Kemunto, Emuraya, D. Ongoto, J. Amenya D. (2012) towards inclusive and equitable basic education system: Kenyans experience IDEA

[16].Scheeler, M. C., Congdon, M., \& Stansbery, S. (2010). Providing Immediate Feedback to Co-Teachers Through Bug-in-Ear Technology: An Effective Method of Peer Coaching in Inclusion Classrooms. Teacher 
Education and Special Education: The Journal of the Teacher Education Division of the Council for Exceptional Children, 33(1), 83-96. https://doi.org/10.1177/0888406409357013

[17].Seo, B., Kim, J., \& Shin, H. (2014). Metaphors Analysis of College Students concerning 'College Students with Disabilities' and 'College for Students with Disabilities and Students without Disabilities'. Special Education Research, 13(3), 317. https://doi.org/10.18541/ser.2014.10.13.3.317

[18].Seung-mo, K. (2016). A Study of Content Suitability Analysis in the Special Education Science Textbook from the Viewpoint of Science Inquiry Activities. Journal of Special Education for Curriculum and Instruction, 9(3), 47-66. https://doi.org/10.24005/seci.2016.9.3.47

[19].UNESCO (2008). Education for all global monitoring report pans UNESCO Publishing

[20].Wafula, R. W. (2012). Early identification of learning disabilities among standard three pupils of public primary schools in Butere District, Kenya. Kenyatta University. 